SJ Quinney College of Law, University of Utah

Utah Law Digital Commons

Utah Law Faculty Scholarship

Utah Law Scholarship

$10-2018$

\title{
State of Arizona v. Guy James Goodman: On Petition for a Writ of Certiorari to the Arizona Supreme Court
}

\author{
Allyson N. Ho \\ Gibson, Dunn \& Crutcher LLP \\ Paul Cassell \\ S.J. Quinney College of Law, University of Utah, paul.cassell@law.utah.edu \\ Bradley Hubbard \\ University of Chicago Law School \\ Cristina M. Squiers \\ Gibson, Dunn \& Crutcher LLP \\ Elizabeth A. Kiernan \\ Gibson, Dunn \& Crutcher LLP \\ See next page for additional authors
}

Follow this and additional works at: https://dc.law.utah.edu/scholarship

\section{Recommended Citation}

Ho, Allyson N.; Cassell, Paul; Hubbard, Bradley; Squiers, Cristina M.; Kiernan, Elizabeth A.; and Twist, Steven J., "State of Arizona v. Guy James Goodman: On Petition for a Writ of Certiorari to the Arizona Supreme Court" (2018). Utah Law Faculty Scholarship. 137.

https://dc.law.utah.edu/scholarship/137

This Brief is brought to you for free and open access by the Utah Law Scholarship at Utah Law Digital Commons. It has been accepted for inclusion in Utah Law Faculty Scholarship by an authorized administrator of Utah Law Digital Commons. For more information, please contact

valeri.craigle@law.utah.edu. 
Authors

Allyson N. Ho, Paul Cassell, Bradley Hubbard, Cristina M. Squiers, Elizabeth A. Kiernan, and Steven J. Twist 
No. $18-391$

IN THE

Supreme Uaurt of the Zlinted States

\author{
STATE OF ARIZONA, \\ v. \\ GUY JAMES GOODMAN,
}

Petitioner,

Respondent.

\begin{abstract}
On Petition for a Writ of Certiorari to the Arizona Supreme Court
\end{abstract}

\title{
MOTION FOR LEAVE TO FILE AND BRIEF FOR ARIZONA VOICE FOR CRIME VICTIMS, INC., MEMORY OF VICTIMS EVERYWHERE TO RESCUE JUSTICE, AND NATIONAL CRIME VICTIM LAW INSTITUTE AS AMICI CURIAE IN SUPPORT OF PETITIONER
}

STEVEn J. Twist

ARIZONA VOICE FOR

CRIME VICTIMS, INC.

P.O. Box 12722

Scottsdale, Arizona 85267

Paul G. CASSEll

S.J. QUINNEY COLLEGE OF LAW AT THE UNIVERSITY OF UTAH 383 South University Street Salt Lake City, Utah 84112
ALLYSON N. Ho

Counsel of Record

BRADLEY G. HUBBARD

CRISTINA M. SQUIERS

ELIZABETH A. KIERNAN

GIBSON, DUNN \& CRUTCHER LLP

2100 McKinney Avenue

Suite 1100

Dallas, Texas 75201

(214) 698-3100

aho@gibsondunn.com 


\section{MOTION FOR LEAVE TO FILE BRIEF FOR ARIZONA VOICE FOR CRIME VICTIMS, INC., MEMORY OF VICTIMS EVERYWHERE TO RESCUE JUSTICE, AND NATIONAL CRIME VICTIM LAW INSTITUTE AS AMICI CURIAE IN SUPPORT OF PETITIONER}

Arizona Voice for Crime Victims, Inc. (AVCV) is an Arizona nonprofit corporation that works to promote and protect crime victims' interests throughout the criminal justice process. To achieve these goals, AVCV empowers victims of crime through legal advocacy and social services. AVCV also provides continuing legal education to the judiciary, lawyers, and law enforcement.

AVCV seeks to foster a fair justice system that (1) provides crime victims with resources and information to help them seek immediate crisis intervention; (2) informs crime victims of their rights under the laws of the United States and Arizona; (3) ensures that crime victims fully understand those rights; and (4) promotes meaningful ways for crime victims to enforce their rights, including through direct legal representation.

Memory of Victims Everywhere to Rescue Justice (MOVE) was founded in California in 1988 by Gary and Collene Campbell to fight for justice and rights for all crime victims. The Campbells' son, Scott, was brutally murdered at the age of 27 when he was lured onto a Cessna airplane by a high school friend, flown out to sea, beaten, and thrown overboard in an apparent robbery attempt. Since its founding, MOVE has been a national leader in calling for the 
enactment of constitutional rights for crime victims and for the vigorous enforcement of criminal laws to keep our communities and people safe.

The National Crime Victim Law Institute (NCVLI) is a nonprofit educational organization located at Lewis \& Clark Law School in Portland, Oregon. NCVLI's mission is to actively promote balance and fairness in the justice system through crime victim-centered legal advocacy, education, and resource sharing. NCVLI accomplishes its mission through education and training; technical assistance to attorneys; promotion of the National Alliance of Victims' Rights Attorneys; research and analysis of developments in crime victim law; and provision of information on crime victim law to crime victims and other members of the public. In addition, NCVLI actively participates as amicus curiae in cases across the Nation that involve crime victims' rights.

Amici have a keen interest in ensuring that courts have the benefit of information and policy insights as they perform the difficult task of safeguarding the rights of the accused while also vindicating the rights of crime victims - not to mention protecting the wider community.

Measures like the one at issue in this case further those goals by protecting victims' rights, bringing offenders to justice, and safeguarding communities. They do not offend due process because the high risk that a sex offender will reoffend, combined with the devastating harm to victims and communities and the high risk of flight, justifies the determination that-certainly where the proof is evident or 
presumption great-defendants charged with sexual assault are categorically ineligible for bail.

Amici are concerned that if permitted to stand, the decision below will deprive the States of a muchneeded tool for keeping sexual assault victims and communities safe. Nothing in the Constitution requires-much less permits-that unfortunate result. Amici respectfully request that the Court grant their motion, grant the petition, and reverse the judgment below.

Respectfully submitted.

Steven J. Twist

ARIZONA VOICE FOR

CRIME VICTIMS, INC.

P.O. Box 12722

Scottsdale, Arizona 85267

PAUl G. CASSELL ${ }^{\dagger}$

S.J. QUINNEY COLLEGE OF LAW AT THE UNIVERSITY OF UTAH 383 South University Street

Salt Lake City, Utah 84112
ALLYSON N. Ho

Counsel of Record

BRADLEY G. HUBBARD

CRISTINA M. SQUIERS

ELIZABETH A. KIERNAN

GIBSON, DUNN \& CRUTCHER LLP

2100 McKinney Avenue

Suite 1100

Dallas, Texas 75201

(214) 698-3100

aho@gibsondunn.com

\section{Counsel for Amici Curiae}

October 29, 2018

\footnotetext{
$\dagger$ Institutional information provided only for identification purposes; does not imply institutional endorsement.
} 


\title{
TABLE OF CONTENTS
}

\author{
Page \\ TABLE OF AUTHORITIES................................. ii \\ INTEREST OF AMICI CURIAE ............................1 \\ STATEMENT …................................................. 3 \\ SUMMARY OF ARGUMENT ................................ 7 \\ ARGUMENT ................................................11 \\ I. Sexual Assault Is A Sufficient Proxy \\ For Future Dangerousness. .......................11 \\ A. Sex Offenders Reoffend At Alar- \\ mingly High Rates.............................11 \\ B. The Harm Threatened By Sex- \\ Offender Recidivism Is Particularly \\ Heinous And Damaging To Victims \\ And Communities. \\ II. Defendants Facing Sexual Assault \\ Charges Present Serious Flight Risks.........17 \\ CONCLUSION ..................................................23
}


ii

\section{TABLE OF AUTHORITIES}

\section{Cases}

Page(s)

Arizona v. Martinez, 138 S. Ct. 146 (2017) ............................................5

Bell v. Wolfish,

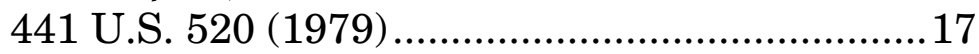

Carlson v. Landon,

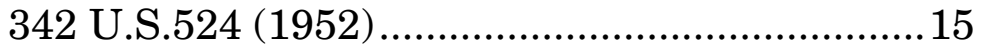

Coker v. Georgia, 433 U.S. 584 (1977) ................................. 7, 15, 16

Conn. Dep't of Pub. Safety v. Doe,

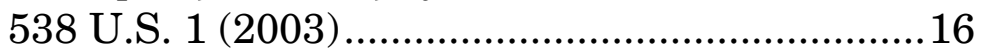

Kansas v. Hendricks, 521 U.S. 346 (1997) .19

McKune v. Lile, 536 U.S. 24 (2002) $.7,15,16$

Packingham v. North Carolina, 137 S. Ct. 1730 (2017). .16

Seling v. Young, 531 U.S. 250 (2001) .19

Simpson v. Miller, 377 P.3d 1003 (Ariz. Ct. App. 2016) .18

Simpson v. Miller, 387 P.3d 1270 (Ariz. 2017)................................5, 6

Smith v. Doe, 538 U.S. 84 (2003) ........................................passim

United States v. Kebodeaux, 570 U.S. 387 (2013) 
United States v. Salerno, 481 U.S. 739 (1987).

passim

\section{Statutes}

42 Pa. C.S. § 6401 et seq............................................. 19

42 Pa. C.S. § 9799.14 ...........................................20

42 Pa. C.S. § 9799.15 ..........................................20

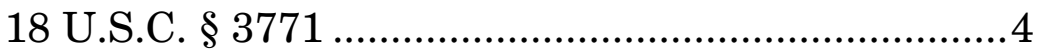

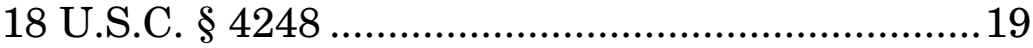

725 Ill. Comp. Stat. 205/1.01 et seq. ..........................18

Ala. Code § 15-20A-3 ….........................................20

Ala. Code § 15-20A-10 ............................................20

Alaska Stat. § 12.55.125 ..........................................18

Ariz. Rev. Stat. § 13-1401 …...................................14

Ariz. Rev. Stat. § 13-1406 ..................................passim

Ariz. Rev. Stat. § 13-3821 ................................... 8, 20

Ariz. Rev. Stat. § 13-3822 …...................................20

Ariz. Rev. Stat. § 13-3824 .......................................20

Ariz. Rev. Stat. § 13-3825 ........................................20

Ariz. Rev. Stat. § 13-3827 ........................................20

Ariz. Rev. Stat. § 13-3961 ….................................. 3,9

Ariz. Rev. Stat. § 36-3701 et seq. .......................... 8, 18

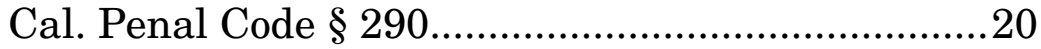

Cal. Penal Code § 290.012.......................................20

Cal. Welf. \& Inst. Code $\S 6600$ et seq ..........................18

Colo. Rev. Stat. § 16-22-103 .....................................20 
Colo. Rev. Stat. § 16-22-108 …................................20

Fla. Stat. § 394.910 et seq. .....................................18

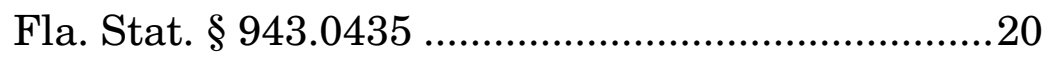

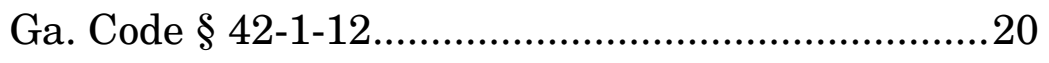

Haw. Rev. Stat. § 846E-2 …………………...........20

Idaho Code $\S 18-8310$..............................................20

Idaho Code § 18-8307 ............................................20

Iowa Code § 229A.1 et seq..........................................19

Kan. Stat. § 59-29a01 et seq.......................................19

Mass. Gen. Laws ch. 123A, § 1 et seq. ........................19

Mass. Gen. Laws ch. 276, § 20D ................................. 9

Minn. Stat. § 253B.01 et seq. ....................................19

Mo. Rev. Stat. $§ 632.480$ et seq..................................19

Mo. Stat. § 589.400 ..................................................20

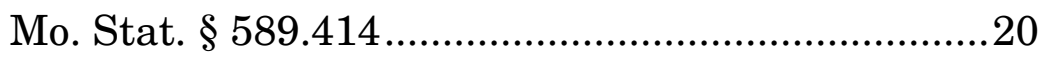

Mont. Code § 45-5-503 ............................................ 18

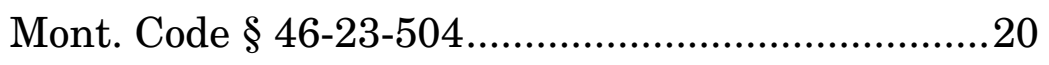

Mont. Code \$46-23-506..........................................20

N.D. Cent. Code $\S 25-03.3-01$ et seq...........................19

N.H. Rev. Stat. § 135-E et seq....................................19

N.H. Rev. Stat. § 597:1-c ............................................ 10

N.J. Stat. § 30:4-27.26 et seq.......................................19

N.M. Stat. § 29-11A-4 ...............................................20

N.M. Stat. § 29-11A-5 ................................................20

N.Y. Mental Hyg. Law $§ 10.01$ et seq........................19 
Neb. Rev. Stat. § 28-105....................................... 18

Neb. Rev. Stat. § 28-319..................................... 18

Neb. Rev. Stat. $\S 29-4001.01$................................20

Neb. Rev. Stat. $\$ 29-4005$.....................................20

Neb. Rev. Stat. § 71-1201 et seq............................19

S.C. Code $\S 44-48-10$ et seq................................... 19

Tenn. Stat. $\S$ 39-13-502 ......................................... 18

Tenn. Stat. $\S$ 39-13-503 ..................................... 18

Tenn. Stat. $\S 40-35-111$........................................ 18

Tenn. Stat. $\S$ 40-39-202 ....................................21

Tenn. Stat. § 40-39-207 .....................................20

Tex. Health \& Safety Code $\S 841.001$ et seq.............19

Utah Code $\$$ 76-5-402 .......................................... 18

Va. Code $\$$ 37.2-900 et seq. ..................................... 19

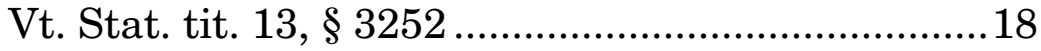

Wash. Rev. Code $\S 71.09 .010$ et seq. .......................19

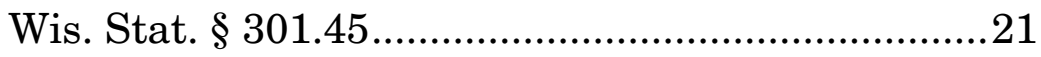

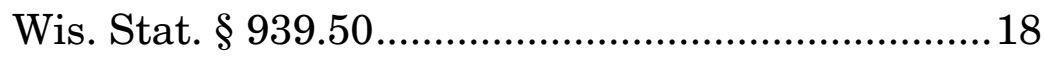

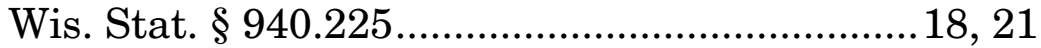

Wis. Stat. § 980.01 et seq..................................... 19

Wyo. Stat. § 7-19-302 ......................................21

Wyo. Stat. § 7-19-304 .....................................21

\section{Constitutional Provisions}

Ala. Const. art. I, $\S 16$........................................ 9

Alaska Const. art I, $\S 11$..................................... 9 


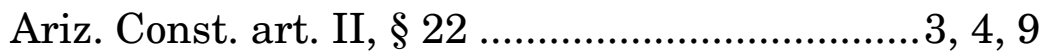

Ark. Const. art. II, § 8 ............................................ 9

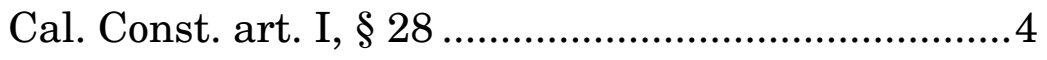

Colo. Const. art. II, $\S 19$........................................... 9

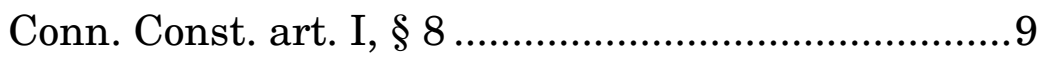

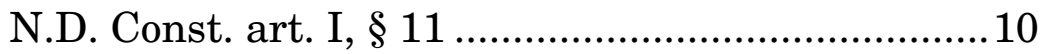

N.M. Const. art. II, § 13 .........................................10

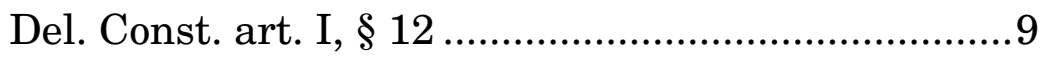

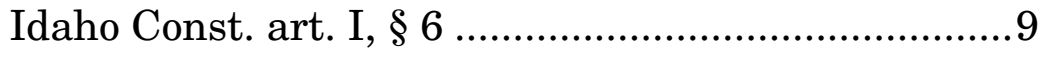

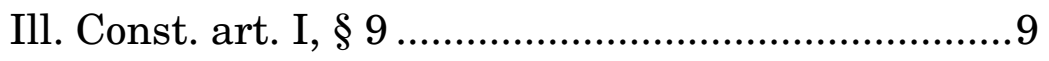

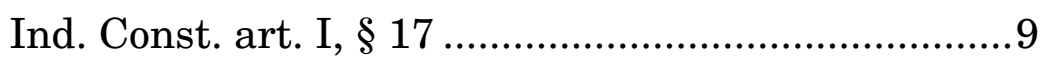

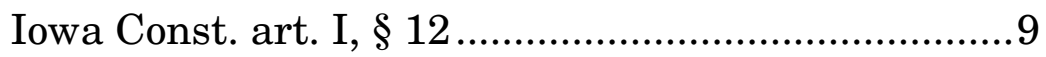

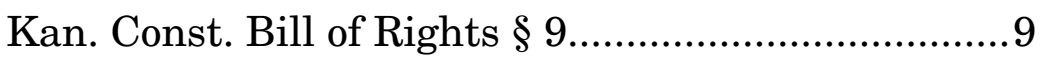

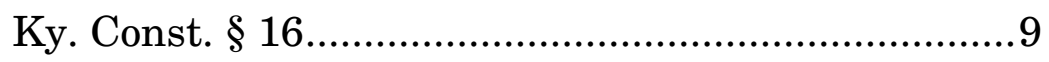

La. Const. art. I, § 18...............................................

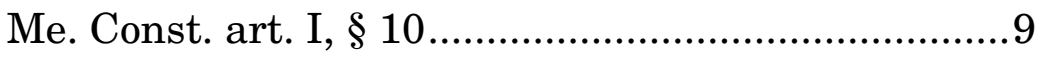

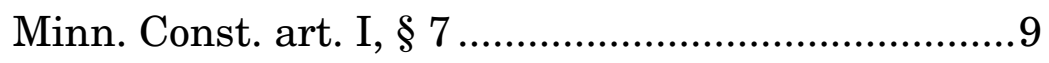

Miss. Const. art. III, $\S 29$........................................

Mo. Const. art. I, § 20............................................. 9

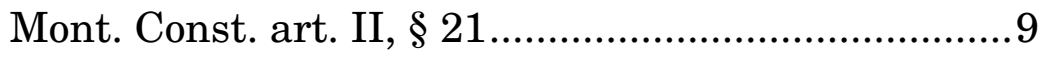

Neb. Const. art. I, § 9 .............................................. 10

Nev. Const. art. I, § 7 .............................................10

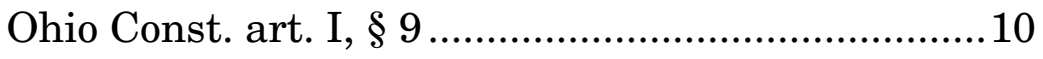

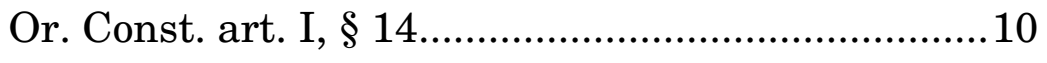

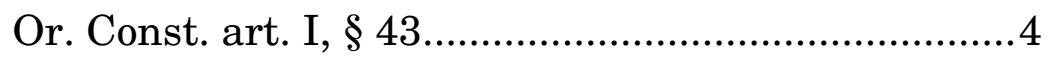


Pa. Const. art. I, § 14........................................... 10

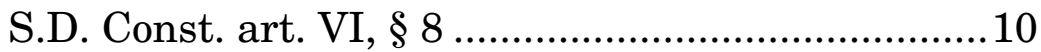

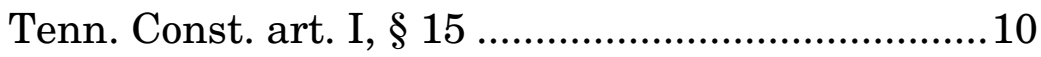

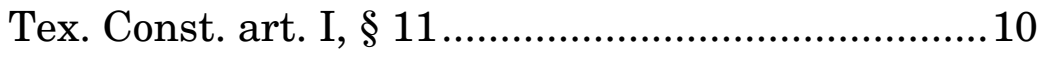

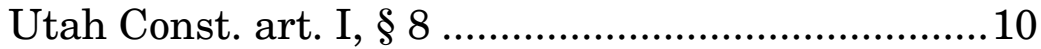

Wash. Const. art. I, § 20.........................................10

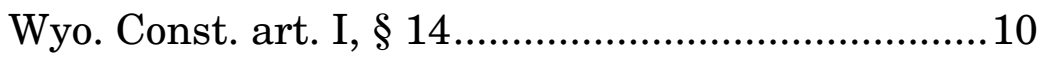

\section{Other Authorities}

Andrew J.R. Harris \& R. Karl Hanson, Sex Offender Recidivism: A Simple

Question 2004-03 (Pub. Safety \&

Emergency Preparedness Can. 2004)

Brian A. Reaves, Felony Defendants in Large Urban Counties, 2009-Statistical Tables (DOJ 2013)

Jeslyn A. Miller,

Sex Offender Civil Commitment:

The Treatment Paradox, 98 Cal. L. Rev. 2093 (2010)

Matthew R. Durose et al., Recidivism of Prisoners Released in 30 States in 2005: Patterns from 2005 to 2010-Supplemental Tables (DOJ 2016)

Matthew R. Durose et al., Recidivism of Prisoners Released in 30 States in 2005: Patterns from 2005 to 2010 (DOJ 2014) 
viii

Michael Planty et al.,

Female Victims of Sexual Violence, 1994-

2010 (DOJ 2013)

Nat'l Inst. of Just.,

Rape and Sexual Violence (DOJ 2017).................3

Nat'l Sexual Violence Res. Ctr.,

Impact of Sexual Violence: Fact Sheet (2010) .......16

Office of Pub. Affairs,

An Updated Definition of Rape (DOJ 2012)..........3

Office of Sex Offender Sentencing, Monitoring,

Apprehending, Registering, and Tracking

(SMART), Sex Offender Registration and

Notification in the United States: Current

Case Law and Issues (DOJ 2018)

Patrick A. Langan et al.,

Recidivism of Sex Offenders Released from

Prison in 1994 (DOJ 2003)

R. Karl Hanson \& Kelly Morton-Bourgon,

Predictors of Sexual Recidivism: An

Updated Meta-Analysis 2004-02 (Pub. Safety

\& Emergency Preparedness Can. 2004)

Richard Tewksbury,

Exile at Home: The Unintended Collateral

Consequences of Sex Offender Residency

Restrictions,

42 Harv. C.R.-C.L.L. Rev. 531 (2007)

Roger Przybylski,

Adult Sex Offender Recidivism,

in Sex Offender Mgmt. Assessment \&

Planning Initiative (DOJ 2017)

12,14 
Shoba Sreenivasan et al.,

Expert Testimony in Sexually Violent

Predator Commitments: Conceptualizing

Legal Standards of "Mental Disorder" and

"Likely To Reoffend,"

31 J. Am. Acad. Psych. \& L. 471 (2003) ...............19

Thomas H. Cohen \& Tracey Kyckelhahn,

Felony Defendants in Large Urban

Counties, 2006 (DOJ 2010) ...................................14 


\section{BRIEF FOR AMICI CURIAE IN SUPPORT OF PETITIONER}

\section{INTEREST OF AMICI CURIAE*}

Arizona Voice for Crime Victims, Inc. (AVCV) is an Arizona nonprofit corporation that works to promote and protect crime victims' interests throughout the criminal justice process. To achieve these goals, AVCV empowers victims of crime through legal advocacy and social services. AVCV also provides continuing legal education to the judiciary, lawyers, and law enforcement.

AVCV seeks to foster a fair justice system that (1) provides crime victims with resources and information to help them seek immediate crisis intervention; (2) informs crime victims of their rights under the laws of the United States and Arizona; (3) ensures that crime victims fully understand those rights; and (4) promotes meaningful ways for crime victims to enforce their rights, including through direct legal representation.

Memory of Victims Everywhere to Rescue Justice (MOVE) was founded in California in 1988 by Gary and Collene Campbell to fight for justice and rights for all crime victims. The Campbells' son, Scott, was

* Pursuant to Supreme Court Rule 37.6, amici represent that this brief was not authored in whole or in part by any party or counsel for any party. No person or party other than amici, their members, or their counsel made a monetary contribution to the preparation or submission of this brief. Counsel of record for all parties received notice of the filing of this brief in compliance with Supreme Court Rule 37.2. Petitioner consented to the filing of this brief, but Respondent withheld consent. 
brutally murdered at the age of 27 when he was lured onto a Cessna airplane by a high school friend, flown out to sea, beaten, and thrown overboard. Since its founding, MOVE has been a national leader in calling for the enactment of constitutional rights for crime victims and for the vigorous enforcement of criminal laws to keep our communities and people safe.

The National Crime Victim Law Institute (NCVLI) is a nonprofit educational organization located at Lewis \& Clark Law School in Portland, Oregon. NCVLI's mission is to actively promote balance and fairness in the justice system through crime victim-centered legal advocacy, education, and resource sharing. NCVLI accomplishes its mission through education and training; technical assistance to attorneys; promotion of the National Alliance of Victims' Rights Attorneys; research and analysis of developments in crime victim law; and provision of information on crime victim law to crime victims and other members of the public. In addition, NCVLI actively participates as amicus curiae in cases across the Nation that involve crime victims' rights.

Amici have a keen interest in ensuring that courts have the information and policy insights needed to safeguard the constitutional rights of the accused while vindicating the rights of crime victims-not to mention protecting the wider community. Nothing in the Constitution prohibits the States from empowering courts to protect crime victims by denying bail when-as determined by a court after a full and fair adversarial process - the proof is evident that a defendant committed a sexually violent offense. This Court's intervention is sorely needed to ensure that 
when, as here, States act well within the Constitution to protect crime victims and keep communities safe, courts are not permitted to improperly thwart those efforts.

\section{STATEMENT}

1. In 2002, over 80 percent of Arizona voters approved Proposition 103, which amended Arizona's constitution by rendering a defendant categorically ineligible for bail if "the proof is evident or the presumption great" that he committed sexual assault. Ariz. Const. art. II, § 22(A)(1); Ariz. Rev. Stat. § 133961(A)(2).

Sexual assault under Arizona law is rape: "intentionally or knowingly engaging in sexual intercourse or oral sexual contact with any person without consent." Ariz. Rev. Stat. § 13-1406(A). ${ }^{1}$

Arizonans approved Proposition 103 "both to ensure that sexual predators facing potential life sentences would be present for trial and to keep 'rapists and child molesters' from endangering others while awaiting trial." Pet. App. 9. As one legislator explained, "sexual predators *** know they could be facing lifetime incarceration' and therefore 'ha[ve] no incentive to ever return' to court, making Proposition

1 See Nat'l Inst. of Just., Rape and Sexual Violence (DOJ 2017), https://www.nij.gov/topics/crime/rape-sexual-violence/Pages/ welcome.aspx ("Most statutes currently define rape as nonconsensual oral, anal, or vaginal penetration of the victim by body parts or objects"); Office of Pub. Affairs, An Updated Definition of Rape (DOJ 2012), https://www.justice.gov/archives/opa/blog/ updated-definition-rape (defining rape as "penetration, no matter how slight, of the vagina or anus with any body part or object, or oral penetration by a sex organ of another person, without the consent of the victim"). 
103 necessary to "keep dangerous sexual predators off our streets." Pet. App. 9 (alterations in original). Proposition 103 was adopted "to 'prevent the worst sexual predators from jumping bail or even simply walking our neighborhoods,' stopping 'rapists and child molesters' from reoffending, and treating 'bail for rapists and child molesters $* * *$ like bail for murderers." Pet. App. 9-10 (alterations in original).

By denying bail when-as determined by a court after an adversarial proceeding-the proof is evident that a defendant committed a sexually violent offense, Proposition 103 helps ensure that victims of sexual assault receive the full panoply of protections they are guaranteed by the Arizona constitutionincluding the right to be "treated with fairness, respect, and dignity" and to be "free from intimidation, harassment, or abuse, throughout the criminal justice process.” Ariz. Const. art. II, § 2.1(A)(1). ${ }^{2}$

2. Respondent Guy James Goodman-after being confronted with DNA evidence-pleaded guilty to sexual assault for creeping into his victim's bedroom, crawling into bed with her, pulling down her underwear, and penetrating her with his fingers. Pet. App. 5-6, 88.

2 Arizona is by no means unique in guaranteeing crime victims certain constitutionally protected rights. See, e.g., Cal. Const. art. I, §28(b)(1) ("a victim shall $* * *$ be free from intimidation, harassment, and abuse, throughout the criminal or juvenile justice process"); Or. Const. art. I, § 43(1)(a) (granting victims the "right to be reasonably protected from the criminal defendant or the convicted criminal throughout the criminal justice process"). Cf. 18 U.S.C. § 3771(a)(1), (a)(8) (guaranteeing victims right "to be reasonably protected from the accused" and "to be treated with fairness and with respect"). 
Just before his arrest, the Arizona Supreme Court held that Proposition 103 could not be constitutionally applied to defendants charged with sexual conduct with a minor. Simpson v. Miller, 387 P.3d 1270 (Ariz. 2017), cert. denied sub nom. Arizona v. Martinez, 138 S. Ct. 146 (2017). The court held that criminal sexual conduct with a minor was not a sufficient proxy for future dangerousness because, in addition to criminalizing the defendant's conductmolesting children under fifteen when he was in his twenties and thirties-the statute also arguably criminalized consensual sex between teenagers. Id. at 1278.

Relying on Simpson, the trial court in the instant case ruled that Goodman was entitled to bond. Even though the proof was evident that Goodman sexually assaulted the victim, the court concluded that the State failed to prove he presented "a substantial danger to other persons or the community." Pet. App. 84.

The court of appeals reversed, holding that "[s]exual assault remains a non-bailable offense." Pet. App. 76. Unlike sexual conduct with a minor, which encompasses statutory rape, "the nonconsensual nature of [sexual assault] fulfills the requirement for finding inherent dangerousness." Pet. App. 81.

3. In a sharply divided 4-3 decision, the Arizona Supreme Court reversed, ruling that data regarding sex offenders' high "post-conviction recidivism rates do not inherently demonstrate that a person charged with sexual assault will likely commit another sexual assault if released pending trial." Pet. App. 16 (em- 
phasis added); see also Pet. App. 13 (requiring proof "that most persons charged with sexual assault, or even a significant number, would likely commit another sexual assault or otherwise dangerous crime pending trial if released on bail"). The court brushed aside the risk that someone potentially facing life imprisonment, involuntary commitment, and lifetime registration as a sex offender inherently poses a flight risk because not all offenders will face such dire consequences. Pet. App. 11.

4. Justice Clint Bolick-author of the Simpson majority opinion-dissented, joined by two other justices. His dissent emphasized that "sexual assault is by definition a uniquely horrific act, in which a person's most intimate parts are violated through force, coercion, or deception." Pet. App. 24. He would have held that Proposition 103 withstands scrutiny because this Court has made clear that "a state may categorically regulate sex offenders as a class for public safety purposes, both because of the uniquely horrific nature of the crimes and sex offenders' propensity for recidivism." Pet. App. 26-27 (citing Smith v. Doe, 538 U.S. 84 (2003)). Justice Bolick concluded by "urg[ing]" this Court to intervene. Pet. App. 30-31.

Justice Gould, joined by Justice Lopez, authored a separate dissent. He criticized the majority for departing from this Court's decision in United States v. Salerno, 481 U.S. 739 (1987), concerning the proper standard for facial constitutional challenges, and for imposing "an impossible standard" on the State. Pet. App. 31-32. 


\section{SUMMARY OF ARGUMENT}

As this Court recognized in Smith v. Doe, releasing sex offenders pending trial presents a substantial danger to the community because the "risk of recidivism posed by sex offenders is 'frightening and high." 538 U.S. 84, 103 (2003) ("high rate of recidivism among convicted sex offenders" means they pose risk of future "dangerousness as a class"). When "sex offenders reenter society, they are much more likely than any other type of offender to be rearrested for a new rape or sexual assault." McKune v. Lile, 536 U.S. 24, 32 (2002) (plurality) ("Sex offenders are a serious threat in this Nation."); see also United States v. Kebodeaux, 570 U.S. 387, 395-96 (2013) ("recidivism rates among sex offenders are higher than the average for other types of criminals").

The damage inflicted when sex offenders reoffend is drastic and severe-for both victims and their communities. "Sexual assault is by definition an extremely dangerous crime." Pet. App. 23 (Bolick, J., dissenting). As this Court has explained, sexual assault "is highly reprehensible, both in a moral sense and in its almost total contempt for the personal integrity and autonomy" of the victim-“[s]hort of homicide, it is the "ultimate violation of self." Coker v. Georgia, 433 U.S. 584, 597-98 (1977); see also Pet. App. 11 (majority) ("sexual assault is a deplorable crime that endangers and dehumanizes victims").

Because the punishment should fit the crime, the consequences of a sexual assault conviction are (or at least strive to be) as drastic and severe as the harm inflicted on victims and communities. Convicted sex offenders face not only potentially lengthy prison 
sentences, but also the possibility of indefinite involuntary commitment after completing that sentence. E.g., Ariz. Rev. Stat. § 13-1406(B)-(D) (providing sentencing range of five years to life, with no possibility of parole); Ariz. Rev. Stat. § 36-3701 et seq. (involuntary commitment).

Even after their release from state custody, sex offenders face serious collateral consequences of their conviction-in particular, having to register as a convicted sex offender and comply with the attendant regulatory schemes. E.g., Ariz. Rev. Stat. $\S 13-3821$ et seq.

As several members of this Court have noted, registering as a sex offender entails numerous, lifelong social, economic, and psychological consequences. See, e.g., Smith, 538 U.S. at 99 (describing "the attendant humiliation" and "public shame" that are "collateral consequence[s]" of registration); id. at 109 \& n.* (Souter, J., concurring) (describing "the severity of the burdens imposed $* * *$ such as exclusion from jobs or housing, harassment, and physical harm"); id. at 112 (Stevens, J., dissenting) ("It is also clear beyond peradventure that these unique [registration and reporting] consequences of conviction of a sex offense are punitive."); id. at 115-16 (Ginsburg, J., joined by Breyer, J., dissenting) (registration "resemble[s] historically common forms of punishment" and is "punitive in effect").

As a result of these exceedingly serious consequences, releasing sex offenders pending trial presents a substantial danger to the community not only because the "risk of recidivism posed by sex offenders is 'frightening and high," Smith, 538 U.S. at 103 
(majority), but also because the risk of sex offenders fleeing justice is equally high. To address these serious public policy and criminal justice concerns, States across the Nation have taken steps to ensure that sex offenders are brought to justice, victims are protected, and communities are safeguarded.

At issue in this case is one such measuredenying bail in sexual assault cases once a court is satisfied, after a full adversarial hearing, that the "proof" of sexual assault "is evident or the presumption great." Ariz. Const. art. II, § 22(A)(1); Ariz. Rev. Stat. § 13-3961(A)(2).

As the State has ably demonstrated in its petition (at 11-16), the conclusion of the court below that this measured, common-sense approach violates due process cannot be reconciled with this Court's cases, which have made clear that the Constitution does not prohibit denying bail to defendants who present (1) "a continuing danger to the community" or (2) "a risk of flight." United States v. Salerno, 481 U.S. 739, 749 (1987). Nor does the Constitution prohibit categorically denying bail based on the nature of the charged offense. Id. at 753-54. Indeed, thirty-four states categorically deny bail to persons charged with capital offenses, murder, specified sex offenses, or offenses punishable by life imprisonment. ${ }^{3}$ Re-

3 Ala. Const. art. I, § 16; Alaska Const. art I, § 11; Ariz. Const. art. II, § 22; Ark. Const. art. II, § 8; Colo. Const. art. II, $\S 19$; Conn. Const. art. I, § 8; Del. Const. art. I, § 12; Idaho Const. art. I, § 6; Ill. Const. art. I, § 9; Ind. Const. art. I, § 17; Iowa Const. art. I, $\S 12$; Kan. Const. Bill of Rights $\S 9$; Ky. Const. § 16; La. Const. art. I, § 18; Mass. Gen. Laws ch. 276, $\S 20 D$; Me. Const. art. I, § 10; Minn. Const. art. I, § 7; Miss. Const. art. III, § 29; Mo. Const. art. I, § 20; Mont. Const. art. II, 
view is needed to resolve the conflict the decision below creates with this Court's precedent on an exceedingly important issue of constitutional law that affects the criminal justice system, crime victims, and community safety in States across the Nation.

This Court's review is especially needed because of the exceedingly serious implications for victims and their communities if the judgment below is permitted to stand. Given sex offenders' frighteningly high recidivism rates, and the life-altering harm suffered by their victims, Arizona's legislature was entirely reasonable when it opted to categorically deny bail to sexual-assault defendants on the ground that sexual assault is an adequate proxy for future dangerousness-and to build in procedural protections that go above and beyond in ensuring due process. The Constitution does not prohibit States like Arizona and others from taking these steps to ensure sex offenders are brought to justice, victims are protected, and communities are safeguarded.

$\S 21$; N.D. Const. art. I, § 11; N.H. Rev. Stat. § 597:1-c; N.M. Const. art. II, § 13; Neb. Const. art. I, § 9; Nev. Const. art. I, § 7; Ohio Const. art. I, § 9; Or. Const. art. I, § 14; Pa. Const. art. I, $\S 14$; S.D. Const. art. VI, § 8; Tenn. Const. art. I, § 15; Tex. Const. art. I, § 11; Utah Const. art. I, § 8; Wash. Const. art. I, $\S 20$; Wyo. Const. art. I, § 14. 


\section{ARGUMENT}

\section{Sexual Assault Is a Sufficient Proxy FOR FUTURE DANGEROUSNESS.}

It is well established that government has a "legitimate and compelling $* * *$ interest in preventing crime by arrestees." Salerno, 481 U.S. at 749 . Accordingly, a State can categorically deny bail based on the charged offense if it can show that defendants charged with that offense categorically present "a continuing danger to the community." Ibid. Arizona has made its task even easier by limiting the denial of bail to those cases in which a court finds the "proof is evident or the presumption great" that the defendant committed the charged offense.

As over 80 percent of Arizona's electorate recognized in approving Proposition 103, sexual assault is precisely such a crime. Sex offenders have such a "high rate of recidivism" that they present a "substantial risk" of future "dangerousness as a class." Smith, 538 U.S. at 103. And the magnitude of the harm inflicted by these particularly heinous crimes further compels the conclusion that sex offenders categorically present a danger to the community-a danger that justifies their incapacitation pending trial, at least where the proof of their guilt is evident.

\section{A. Sex Offenders Reoffend At Alarmingly High Rates.}

A substantial body of academic literature, supported by data collected by the U.S. Department of Justice, confirms that sex offenders reoffend at extremely high rates-regardless of how reoffending is defined (convictions versus arrests), and regardless of subsequent offense-be it another sex crime, a dif- 
ferent violent crime, or any other type of subsequent crime.

Studies have found that 17 percent of sex offenders were convicted of another sex offense within five years of release-with 21 percent reconvicted within ten years. See, e.g., Andrew J.R. Harris \& R. Karl Hanson, Sex Offender Recidivism: A Simple Question 2004-03 7 (Pub. Safety \& Emergency Preparedness Can. 2004), https://www.publicsafety.gc.ca/cnt/rsrcs/ pblctns/sx-ffndr-rcdvsm/sx-ffndr-rcdvsm-eng.pdf (observing that offenders with prior sex-crime convictions were twice as likely to recidivate); see also Roger Przybylski, Adult Sex Offender Recidivism, in Sex Offender Mgmt. Assessment \& Planning Initiative 107, 111-15, 121 (DOJ 2017), https://smart.gov/SOMAPI/ pdfs/SOMAPI_Full\%20Report.pdf ("The observed sexual recidivism rates of sex offenders range from about 5 percent after three years to about 24 percent after 15 years.").

The recidivism rates are even higher for subsequent arrests of sex offenders for any type of crimean important statistic because "policies aimed at public protection should also be concerned with the likelihood of any form of serious recidivism, not just sexual recidivism." R. Karl Hanson \& Kelly MortonBourgon, Predictors of Sexual Recidivism: An Updated Meta-Analysis 2004-02 4 (Pub. Safety \& Emergency Preparedness Can. 2004), https://www. publicsafety.gc.ca/cnt/rsrcs/pblctns/2004-02-prdctrs-sxl -rcdvsm-pdtd/2004-02-prdctrs-sxl-rcdvsm-pdtd-eng.pdf. ${ }^{4}$

4 In addition, studies show "that some crimes legally labeled as nonsexual in the criminal histories of sex offenders may indeed be sexual in their underlying behavior." Przybylski, Adult 
For example, an analysis of 400,000 state prisoners found that 21 percent of sex offenders were rearrested for a crime within six months of release, 31 percent were rearrested within one year, 44 percent within two years, 51 percent within three years, and 60 percent within five years. Matthew R. Durose et al., Recidivism of Prisoners Released in 30 States in 2005: Patterns from 2005 to 20108 (DOJ 2014), https://www.bjs.gov/content/pub/pdf/rprts05p0510.pdf; see also Patrick A. Langan et al., Recidivism of Sex Offenders Released from Prison in 1994 2, 13 (DOJ 2003), https://www.bjs.gov/content/pub/pdf/rsorp94.pdf (24 percent of sex offenders reconvicted of new offense within three years). Those rates are 10 percent higher than the rate at which murderers were rearrested over the same period. Durose et al., Recidivism of Prisoners at 8.

Indeed, one study shows that over a five-year period, 21.4 percent of sex offenders were rearrested for violent offenses-nearly identical to the 21.7 percent of homicide convicts who were rearrested for violent offenses during that same period. See Matthew R. Durose et al., Recidivism of Prisoners Released in 30 States in 2005: Patterns from 2005 to 2010Supplemental Tables 2 (DOJ 2016), https://www.bjs.gov/ content/pub/pdf/rprts05p0510_st.pdf; see also Langan et al., Recidivism of Sex Offenders at 34 (17 percent of sex offenders rearrested for violent offenses within three years of release).

Sex Offender Recidivism at 108 (although murder and kidnapping are not inherently sexual, "when perpetrated by sex offenders, [they are] usually sexually motivated"). 
Further giving credence to Arizonans' concern about sexual-assault defendants "endangering others while awaiting trial," Pet. App. 9, a Department of Justice study found that a significant number of sex offenders-14 percent-not only reoffend, but also do so while out on bail. Brian A. Reaves, Felony Defendants in Large Urban Counties, 2009-Statistical Tables 15, 17, 20-21 (DOJ 2013), https://www.bjs .gov/content/pub/pdf/fdluc09.pdf (52 percent of sexualassault defendants were released pending trial). ${ }^{5}$ By comparison, none of the murder defendants who were released pending trial were rearrested. Ibid. (noting that 18 percent of murder defendants were released pending trial); see also Thomas $\mathrm{H}$. Cohen \& Tracey Kyckelhahn, Felony Defendants in Large Urban Counties, 20069 (DOJ 2010), https://www.bjs .gov/content/pub/pdf/fdluc06.pdf (reporting similar statistics three years earlier-9 percent of released rapists were rearrested before trial; no released murderer was). ${ }^{6}$ And it is well established that

5 This study defines rape consistent with Arizona's definition of sexual assault. Compare id. at 34, with Ariz. Rev. Stat. $\S \S 13-1406(\mathrm{~A}),-1401(\mathrm{~A})(4)$.

6 Even these already high recidivism rates "are underestimates of the true reoffense rates" for at least two reasons. Przybylski, Adult Sex Offender Recidivism at 108-09. First, no study purports to identify every time a sex offender reoffends, which would be all but impossible. Instead, studies rely on officially recorded metrics, like subsequent arrests. Ibid. ("Because these official statistics reflect only offenses that come to the attention of authorities, they are a diluted measure of reoffending."). Second, sex crimes themselves are significantly underreported, with studies finding that fewer than one-third of victims contact the police. See ibid.; Rachel E. Morgan \& Grace Kena, Criminal Victimization, 20167 (DOJ 2017), https://www .bjs.gov/content/pub/pdf/cv16.pdf (23 percent of rapes and sexu- 
States can categorically deny bail to murder defendants. Salerno, 481 U.S. at 753; Carlson v. Landon, 342 U.S.524, 545-46 (1952).

Given the breadth of academic literature and Department of Justice studies further demonstrating "that recidivism rates among sex offenders are higher than the average for other types of criminals," $\mathrm{Ke}$ bodeaux, 570 U.S. at 395-96 (citing studies), it is hardly surprising that this Court has repeatedly recognized that releasing sex offenders into the community is a perilous gamble. See Smith, 538 U.S. at 103 (noting the "dangerousness" of sex offenders "as a class" due to their "frightening and high" recidivism rates). Indeed, when "convicted sex offenders reenter society, they are much more likely than any other type of offender to be rearrested for a new rape or sexual assault." McKune, 536 U.S. at 33.

\section{B. The Harm Threatened By Sex-Offender Recidivism Is Particularly Heinous And Damaging To Victims And Com- munities.}

Sexual assault "is a deplorable crime that endangers and dehumanizes victims." Pet. App. 11. "Short of homicide, it is the "ultimate violation of self." Coker, 433 U.S. at 597. The Arizona electorate did not run afoul of due process by deciding that to allow a sexual-assault defendant-whose proof of guilt is evident, as established by a court after an adversarial proceeding - to remain free pending trial presents

al assaults reported to police); see also Michael Planty et al., Female Victims of Sexual Violence, 1994-2010 6 (DOJ 2013), https://www.bjs.gov/content/pub/pdf/fvsv9410.pdf (slightly more than one-third of rapes and sexual assaults reported). 
a substantial risk of imposing further harm on both the victim and the community as a whole.

The harm inflicted by sex offenders extends well beyond the over 320,000 annual victims of sexual assault. Because sexual assault "undermines the community's sense of security, there is public injury as well." Id. at 598. In short, "sexual violence tears at the fabric of community well-being." Nat'l Sexual Violence Res. Ctr., Impact of Sexual Violence: Fact Sheet 2 (2010), http://www.nsvrc.org/sites/default/ files/NSVRC_Publicication_Factsheet_Impact-of-sexual -violence.pdf.

In recognition of the catastrophic harms they cause, this Court has stated-in no uncertain terms-that "[s]ex offenders are a serious threat in this Nation." Conn. Dep't of Pub. Safety v. Doe, 538 U.S. 1, 3 (2003) (quoting McKune, 536 U.S. at 32). When "sex offenders reenter society, they are much more likely than any other type of offender to be rearrested for a new rape or sexual assault." Packingham v. North Carolina, 137 S. Ct. 1730, 1739 (2017) (quoting McKune, 536 U.S. at 33). Indeed, sex offenders' "deliberate viciousness $* * *$ may be greater than that of the murderer"-especially when one considers the victims who are left "so grievously injured physically or psychologically that life is beyond repair." Coker, 433 U.S. at 603 (Powell, J., concurring in part and dissenting in part).

Given sex offenders' alarmingly high recidivism rates-and the profound harm suffered by victims and communities-Arizona's electorate acted well within the bounds of due process when it opted to categorically deny bail to sexual-assault defendants 
on the ground that sexual assault is an adequate proxy for future dangerousness (after judicial proceedings to determine that the proof of assault is evident). Further, by keeping dangerous criminals incapacitated pending trial, Proposition 103 also vindicates the state-constitutionally protected rights of victims to be free from intimidation, harassment, and abuse while the criminal trial proceeds. And because Proposition 103 only applies if a court-after a full adversarial hearing-finds that the proof of the defendant's guilt is evident, it goes above and beyond the demands of due process.

\section{Defendants Facing Sexual Assault Charges Present Serious Flight Risks.}

In addition to presenting a danger to the community, "an arrestee may be incarcerated until trial if he presents a risk of flight." Salerno, 481 U.S. at 749 (citing Bell v. Wolfish, 441 U.S. 520, 534 (1979)). As a matter of common sense and human nature, the more severe the potential punishment, the higher the risk that a defendant will flee rather than face trial. Sexual-assault convictions certainly raise the specter of severe punishments-especially considering not only the possibility of a lengthy prison sentence, but also the serious collateral consequences, including involuntary commitment and sex-offender registration.

The punishment for sexual assault in Arizona, as in many States, "ranges from 5.25 years' imprisonment to life imprisonment." Pet. App. 11. See Ariz. Rev. Stat. § 13-1406(B) (no "suspension of sentence, probation, pardon or release from confinement $* * *$ until the sentence imposed by the court has been 
served"); see also Ariz. Rev. Stat. § 13-1406(D) ("if the sexual assault involved the intentional or knowing infliction of serious physical injury, the person may be sentenced to life imprisonment"). ${ }^{7}$

In addition to lengthy prison sentences, sexual assault convictions are accompanied by severe collateral consequences-involuntary civil commitment and sex-offender registration - each of which is sufficient to justify categorically denying bail based on flight risk.

First, a sex offender's confinement does not necessarily conclude at the end of a lengthy prison sentence: "[A]t the completion of a prison sentence a defendant faces potential commitment to the Arizona State Hospital as a sexually violent person for an indefinite period of time." Simpson v. Miller, 377 P.3d 1003, 1012 n.14 (Ariz. Ct. App. 2016) (Gould, J., dissenting) (citing Ariz. Rev. Stat. § 36-3701 et seq.). ${ }^{8}$

7 Other states impose similar penalties for similar sex offenses. E.g., Alaska Stat. § 12.55.125(i)(1) (presumptive twenty-tothirty years' imprisonment, ninety-nine-year maximum); Mont. Code § 45-5-503(1)-(2) (up to life); Neb. Rev. Stat. §§ 28319(1)(a), -105(1) (up to fifty years); Tenn. Stat. \$§ 39-13502(a)(2), -503(a)(2), 40-35-111(b)(1)-(2) (eight-to-sixty years); Utah Code § 76-5-402 (five years to life); Vt. Stat. tit. 13, § 3252 (three years to life); Wis. Stat. §§ 940.225(1)-(2), 939.50(3)(b)(c) (up to sixty years).

8 Arizona is by no means an outlier in this respect. Nineteen other states-along with the federal government-also subject convicted sex offenders to potential involuntary commitment after they have served their sentences. See Jeslyn A. Miller, Sex Offender Civil Commitment: The Treatment Paradox, 98 Cal. L. Rev. 2093, 2128 nn.21-22 (2010) (citing Ariz. Rev. Stat. $\S \S 36-3701$ to -3717; Cal. Welf. \& Inst. Code $§ \$ 6600-09.3$; Fla. Stat. $\S 394.910-394.932 ; 725$ Ill. Comp. Stat. 205/1.01 to /12; 
On several occasions, this Court has upheld state laws that permit the involuntary civil commitment of sex offenders-even after they have served their criminal sentence. See Kansas v. Hendricks, 521 U.S. 346, 356-57 (1997) ("an individual's constitutionally protected interest in avoiding physical restraint may be overridden even in the civil context"); Seling v. Young, 531 U.S. 250 (2001). Indeed, "the practical effect of [involuntary commitment statutes] may be to impose confinement for life." Hendricks, 521 U.S. at 372 (Kennedy, J., concurring).

Second, "[e]very U.S. state, the District of Columbia, the five principal U.S. territories, and over 125 federally recognized Indian tribes" require sex offenders to register as such. Office of Sex Offender Sentencing, Monitoring, Apprehending, Registering, and Tracking (SMART), Sex Offender Registration and Notification in the United States: Current Case Law and Issues 1 (DOJ 2018), https://smart.gov/ caselaw/Case-Law-Update-2018-Compiled.pdf ("Congress has enacted various measures setting 'mini-

Iowa Code § 229A.1 et seq.; Kan. Stat. §§ 59-29a01 to -29a22; Mass. Gen. Laws ch. 123A, §§ 1-16; Minn. Stat. § 253B.01 et seq.; Mo. Rev. Stat. §§ 632.480-632.513; Neb. Rev. Stat. §§ 711201 to -1226; N.H. Rev. Stat. § 135-E et seq.; N.J. Stat. §§ 30:427.26 to -27.38 ; N.Y. Mental Hyg. Law $§ 10.01$ et seq.; N.D. Cent. Code $\S \S 25-03.3-01$ to $-44 ; 42$ Pa. C.S. $\$ \S 6401-09$; S.C. Code $\$ \S 44-48-10$ to -170 ; Tex. Health \& Safety Code $\S \S 841.001-841.007$; Va. Code $\$ \S 37.2-900$ to -921 ; Wash. Rev. Code $\S \S 71.09 .010-71.09 .903$; Wis. Stat. $\$ \S 980.01-980.14 ; 18$ U.S.C. § 4248); see also Shoba Sreenivasan et al., Expert Testimony in Sexually Violent Predator Commitments: Conceptualizing Legal Standards of "Mental Disorder" and "Likely To Reoffend," 31 J. Am. Acad. Psych. \& L. 471, 472, 484 (2003) (citing statutes). 
mum standards' for jurisdictions to implement in their sex offender registration or notifications systems.").

Taking Arizona as an example, convicted sex offenders have ten days to register. Ariz. Rev. Stat. $\S 13-3821(\mathrm{~A})-(\mathrm{B})$. States use this registration to "maintain an internet sex offender website," which includes offenders' names, pictures, addresses, and offenses of conviction. Ariz. Rev. Stat. § 13-3827(A)(B). In addition, if a sex offender moves, he must notify authorities of his new address "in person and in writing" within seventy-two hours of the move. Ariz. Rev. Stat. § 13-3822(A). Authorities then have 45 days to "notify the community of the offender's presence in the community." Ariz. Rev. Stat. §133825(D). That notification "must be disseminated in a nonelectronic format to the surrounding neighborhood, area schools, appropriate community groups and prospective employers"-and a "press release *** must be given to the local electronic and print media to enable information to be placed in a local publication.” Ariz. Rev. Stat. § 13-3825(C)(1).

In many States, including Arizona, sex offenders must update their registration at least annually-for life. Ariz. Rev. Stat. $\S 13-3821(\mathrm{~J}),(\mathrm{M}) .{ }^{9} \quad$ Failing to comply is a felony. Ariz. Rev. Stat. § 13-3824(A).

9 See, e.g., Ala. Code $\$ \S 15-20 A-3,-10$; Cal. Penal Code $\S \S 290$, 290.012; Colo. Rev. Stat. $\S \S 16-22-103,-108$; Fla. Stat. $\S$ 943.0435(11), (14); Ga. Code § 42-1-12(f); Haw. Rev. Stat. $\S 846 \mathrm{E}-2$; Idaho Code $\S \S 18-8307,-8310 ;$ Mo. Stat. $\S 589.400 .4(3)$, 589.414.7(2)(c); Mont. Code $\S \S 46-23-504,-506$; Neb. Rev. Stat. $\S \S 29-4005(\mathrm{~b})(\mathrm{iii}),-4001.01(1)$; N.M. Stat. $\S \S 29-11 \mathrm{~A}-4(\mathrm{~L})(1),-5(\mathrm{D})$; 42 Pa. C.S. $\S \S 9799.15(\mathrm{a})(3),(\mathrm{e}), 9799.14(\mathrm{~d})(5)$; Tenn. Stat. 
Further, registered sex offenders "experience a range of unintended negative consequences that typically have stronger impacts upon sex offenders than other felons." Richard Tewksbury, Exile at Home: The Unintended Collateral Consequences of Sex Offender Residency Restrictions, 42 Harv. C.R.-C.L.L. Rev. 531, 532 (2007) (collecting studies). As this Court has recognized, these collateral consequences include "humiliation" and "public shame." See Smith, 538 U.S. at 99. They also include "exclusion from jobs or housing, harassment, and physical harm," id. at $109 \& \mathrm{n} . *$ (Souter, J., concurring), and "severe stigma." Id. at 111 (Stevens, J., dissenting); see also id. at 115-16 (Ginsburg, J., joined by Breyer, J., dissenting) (registration "calls to mind shaming punishments once used to mark an offender as someone to be shunned").

In sum, while the lengthy sentences for sexual assault alone create a significant, well-recognized flight risk, when considered in tandem with the potential for indefinite involuntary commitment and a lifelong registration requirement, it becomes even clearer that categorically denying bail for defendants facing trial for sexual assault is amply justified by the risk that they will flee rather than face justice.

$$
* \quad * \quad *
$$

Measures like Proposition 103 protect victims' rights, bring offenders to justice, and safeguard communities. They do not offend due process, because the high risk that a sex offender will reoffend,

$\S \S 40-39-207(\mathrm{~g})(1)(\mathrm{B}),-202(31)(\mathrm{B}) ;$ Wis. Stat. $\S \S 301.45,940.225(2)$;

Wyo. Stat. §§ 7-19-302, -304. 
combined with the devastating harm to victims and communities and the high risk of flight, justifies the determination that-certainly where the proof is evident or presumption great-defendants charged with sexual assault are categorically ineligible for bail. If permitted to stand, the decision below will deprive the States of a badly needed tool for keeping sexual assault victims and communities safe. Because nothing in the Constitution requires-much less permits - that untoward result, the petition should be granted and the judgment reversed. 


\section{CONCLUSION}

For the foregoing reasons, the Court should grant the petition for writ of certiorari.

Respectfully submitted.

STEVEn J. Twist

ARIZONA VOICE FOR

CRIME ViCTIMS, INC.

P.O. Box 12722

Scottsdale, Arizona 85267

PAUl G. CASSELL $\dagger$

S.J. QUINNEY COLLEGE OF LAW AT THE UNIVERSITY OF UTAH 383 South University Street Salt Lake City, Utah 84112
ALLYSON N. Ho Counsel of Record BRADLEY G. HUBBARD CRISTINA M. SQUIERS ELIZABETH A. KIERNAN GIBSON, DUNN \& CRUTCHER LLP 2100 McKinney Avenue

Suite 1100

Dallas, Texas 75201

(214) 698-3100

aho@gibsondunn.com

\section{Counsel for Amici Curiae}

October 29, 2018

$\dagger$ Institutional information provided only for identification purposes; does not imply institutional endorsement. 